\title{
Effect of Competence Teacher and Student Learning Environment Program on Student Achievement Light Vehicle Engineering
}

\section{Constantinus Rudy Prihantoro, Mohamad Wafirul Hadi, and Ratu Amilia Avianti}

Mechanical Engineering Education Study Program, Engineering Faculty, State University of Jakarta

\section{Abstract}

This study aims to determine; (1) the influence of teacher competence on student achievement; (2) the influence of the learning environment on student achievement; and (3) the effect of teacher competence and learning environment on student achievement. The studypopulation was all light vehicle engineering students at

Corresponding Author: Constantinus Rudy Prihantoro crudy@unj.ac.id

Received: 11 January 2019 Accepted: 14 February 2019 Published: 25 March 2019

Publishing services provided by Knowledge E

(c) Constantinus Rudy Prihantoro et al. This article is distributed under the terms of the Creative Commons Attribution License, which permits unrestricted use and redistribution provided that the original author and source are credited.

Selection and Peer-review under the responsibility of the 3rd ICTVET 2018 Conference Committee.

\section{G OPEN ACCESS} State Vocational High School 34 Of Jakarta, the sample was grade 11 light vehicle engineering as many as 31 students. The method in this research is survey method with associative approach. The study used secondary data collection techniques with a questionnaire (questionnaire); and primary data even semester learning achievement. The data analysis technique used is simple regression, multiple regression, and $F$ test with a significance level of 0.05 . The results showed that; (1) there is a positive effect of teacher competence on student achievement test results $F_{\text {count }}>16.55 F_{\text {table }}$ 3.32 amounting to $13.21 \%$; (2) there is a positive effect of the learning environment on student achievement test results $F_{\text {count }}>17.55 F_{\text {table }} 3.32$ amounting to $14.21 \%$; (3) there is a positive effect of the teacher competence and learning environment on student achievement test results $F_{\text {count }}>10.33 F_{\text {table }} 3.32$ amounting to $18.02 \%$.

Keywords: competence of teachers, learning environment, student achievement

\section{Introduction}

"National education serves to develop the ability and character development and civilization, is aimed at developing students' potentials in order to become a man of faith and fear of God Almighty, noble, healthy, knowledgeable, skilled, creative, independent, and become citizens of a democratic and responsible "[1].

According to Evans defines that "Vocational education is part of an education system that prepares a person to be able to work in accordance with the field they study"[2]. Competency is a term used extensively by different people in different contexts; hence, 
it is defined in different ways. Teacher education and job performance are two contexts in which this term is used. Competencies are the requirements of a "competency-based" teacher education and include the knowledge, skills and values a teacher-trainee must demonstrate for successful completion of a teacher education programme [3].

Environments that are solely learner centered would not necessarily help students acquire the knowledge and skills necessary to function effectively in society [4]. "Learning achievement is a testament to the success of learning or the ability of a student to perform learning activities in accordance with the weight achieved. The learning achievement is the result obtained by the students after the learning process for a predetermined period together in an educational institution "[5].

The level of learning achievement subjects Light Vehicle Maintenance Engineering effect by several factors, both internal and external factors. "Internal factors emerge from within the students, such as physical, sensory, talents, interests, intelligence, motivation and cognitive ability. As for external factors emerge from outside the student such as environmental and other instruments such as curriculum, teachers, faculty, facilities and facility, administration and management "[6]. After conducting preliminary research on 1 class to get the biggest problem that affects students in teaching and learning activities in the classroom, dominant students choose teacher competencies and students' learning environments which mostly choose from other indicators such as facilities and infrastructure, management, etc.

Departing from the above background, the author is interested in conducting research on the effects of teacher competence and learning environment on student achievement light vehicle engineering program.

The aim of this study was to get information about: (1) Determine the influence of teacher competence on student achievement; (2) Determine the influence of the learning environment on student achievement; (3) Determine the influence of teacher competence and learning environment on student achievement.

\section{Methods}

This study was conducted in April 2017- June 2017 at the 11th grade at the Light Vehicle Engineering Vocational High School 34 Jakarta at Kramat Raya Street No. 93, Salemba, Senen, Central Jakarta. The method used in this research is survey method with associative approach. The population on the entire students of the research is the Light Vehicle Engineering, while the sample under study is 31 students of class 11th grade Light Vehicle Engineering. 


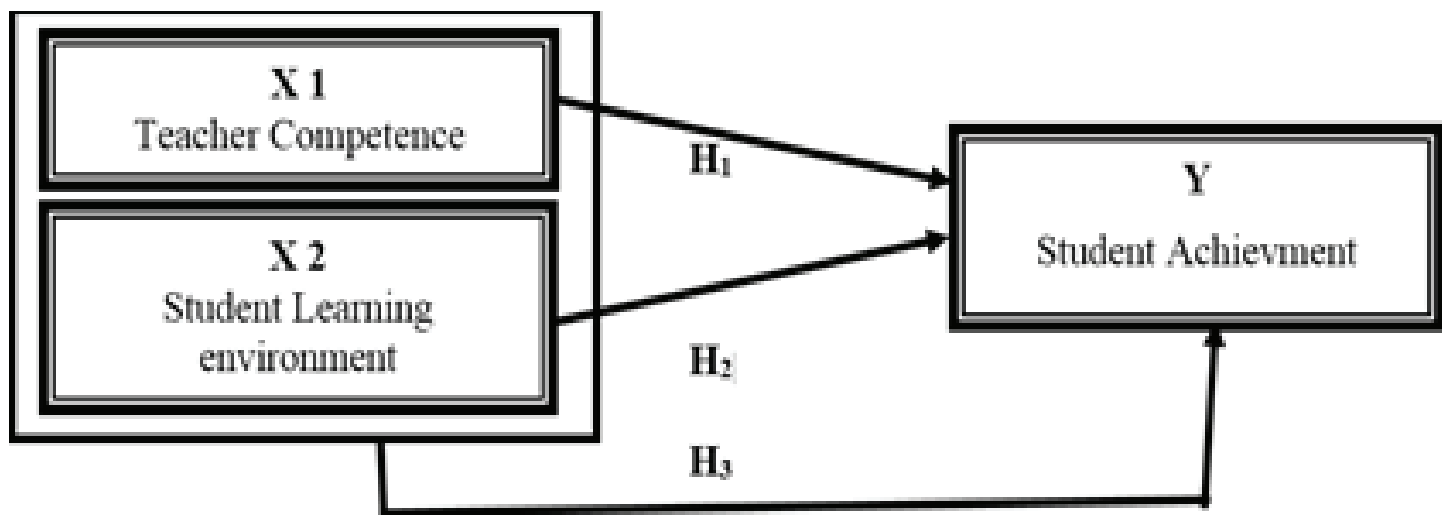

Figure 1: Research framework.

In this study, the independent variable (X1 and $X 2)$ using secondary data collection techniques with a questionnaire. And for the dependent variable $(Y)$ using the primary data learning achievement of the semester. Data analysis techniques used in this study is divided into two prerequisite test analysis consists of data normality test using Chi Square; and hypothesis testing which consists of a simple regression test, multiple regression, and $\mathrm{F}$ test [7].

$$
\begin{gathered}
r_{y x 1 x 2}=\frac{\sqrt{r_{Y X 1}^{2}+r_{Y X 2}^{2}-2 r_{y x 1} \cdot r_{y x 2} \cdot r_{x 1 x 2}}}{1-r_{x 1 x 2}} \\
F_{\text {count }}=\frac{\frac{R^{2}}{k}}{\frac{\left(1-R^{2}\right)}{(n-k-1)}}
\end{gathered}
$$

\section{Results}

\subsection{Data normality test}

TABLE 1: The value of Chi Square.

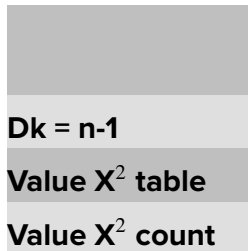

$\begin{gathered}\text { Teachers } \\ \text { Competency }\end{gathered}$
6
12,6
5.54

\begin{tabular}{|c|}
\hline $\begin{array}{c}\text { Learning } \\
\text { Environment }\end{array}$ \\
6 \\
12.6 \\
11.93 \\
\hline
\end{tabular}

In table 1. The value of chi square, $X^{2}$ table $=12.6$ for $\alpha=0.05$ and $\mathrm{df}=6$. Because the $X^{2}$ count $<X^{2}$ it can be concluded that the dissemination of data on all variables are normally distributed [8].

$$
x^{2}=\frac{(f o-f e)^{2}}{f e}
$$




\subsection{Research data}

\subsubsection{Data of teacher competence variable (X1)}

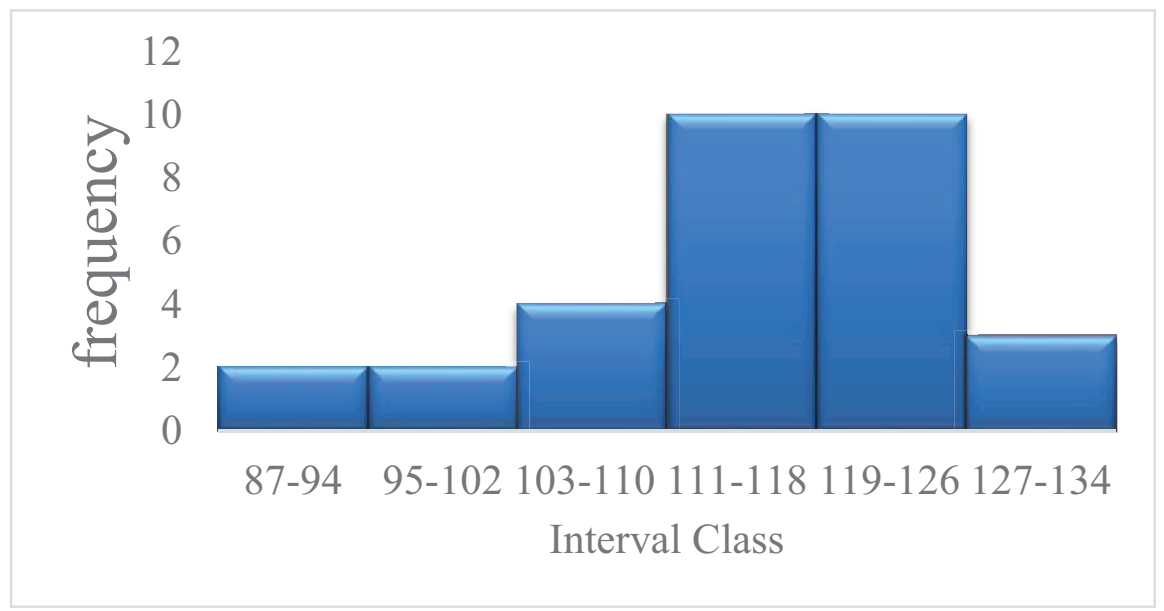

Figure 2: Histogram Variable Teacher Competency.

TABLE 2: Average Score Calculate variable indicator X1 Teacher Competence.

\begin{tabular}{|l|c|c|c|c|c|c|} 
variable & Indicator & $\begin{array}{c}\text { Number } \\
\text { Problem }\end{array}$ & $\begin{array}{c}\text { amount } \\
\text { Item } \\
\text { Problem }\end{array}$ & $\begin{array}{c}\text { Average } \\
\text { Score }\end{array}$ & Total average & Score\% \\
\hline $\begin{array}{r}\text { Teacher } \\
\text { Competence }\end{array}$ & $\begin{array}{l}\text { Pedagogical } \\
\text { Competence }\end{array}$ & 18 & 1863 & 103.5 & 408.23 & 25.35 \\
\hline $\begin{array}{r}\text { Personality } \\
\text { Competence }\end{array}$ & 7 & 7704 & 100.57 & 24.63 \\
$\begin{array}{r}\text { Social } \\
\text { Competence } \\
\begin{array}{r}\text { Professional } \\
\text { Competence }\end{array}\end{array}$ & 4 & 4432 & 108 & 26.45 \\
\hline
\end{tabular}

From the results of calculations such as in table 2, it can be concluded that teacher competencies include; pedagogic competence is $25.35 \%$; $24.63 \%$ personality competence; social competence $26.45 \%$; and professional competence is $23.55 \%$

\subsubsection{Data of student learning environment variable (X2)}

From the results of calculations like in table 3 , it can be concluded that the learning environment of students includes; The indicator of the family environment is $34.52 \%$; school environment indicators are 33.89\%; and community environmental indicators are $31.57 \%$ 


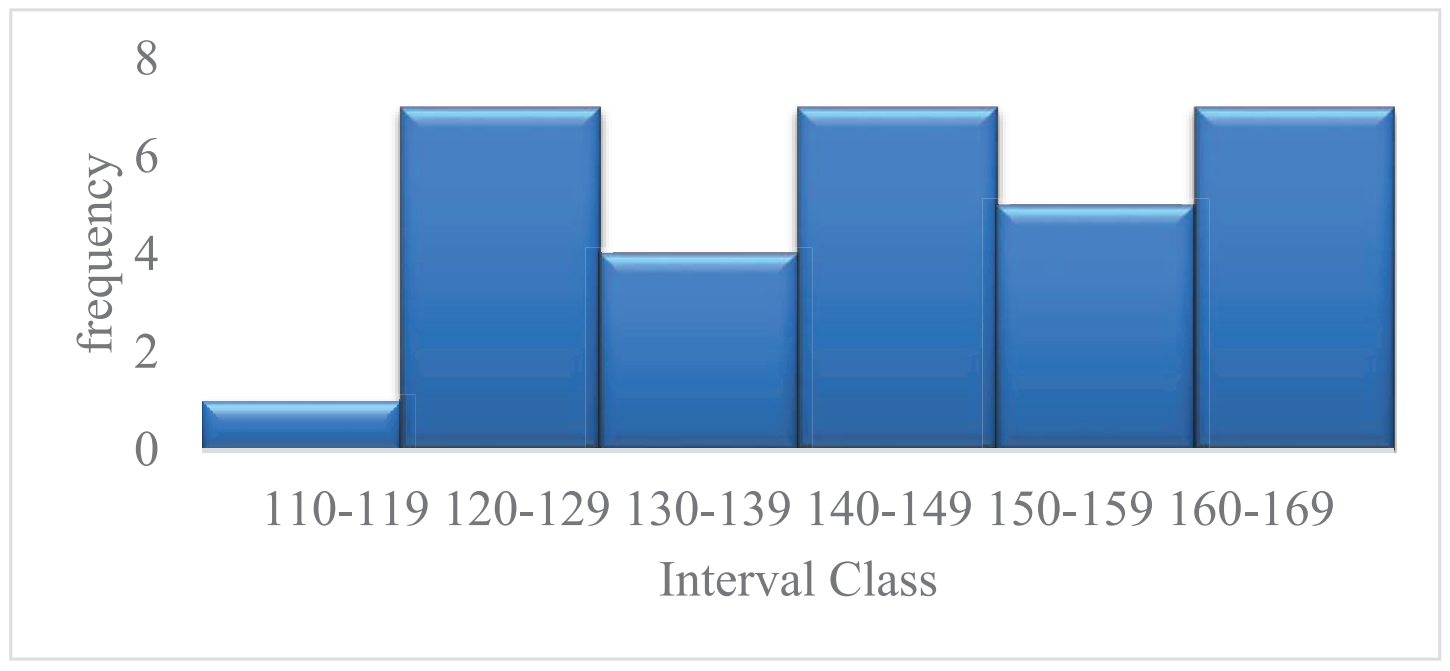

Figure 3: Histogram Variables Learning Environment.

TABLE 3: Average Score Calculate Variable Indicator X2 Student Learning Environment.

\begin{tabular}{|l|l|c|c|c|c|c|}
\hline Variables & Indicators & $\begin{array}{c}\text { Number } \\
\text { Problem }\end{array}$ & $\begin{array}{c}\text { Item } \\
\text { Problem } \\
\text { Number }\end{array}$ & $\begin{array}{c}\text { Average } \\
\text { Score }\end{array}$ & $\begin{array}{l}\text { Number } \\
\text { average }\end{array}$ & Score \% \\
\hline $\begin{array}{l}\text { Learning } \\
\text { Environment }\end{array}$ & $\begin{array}{l}\text { Family } \\
\text { Environment }\end{array}$ & 14 & 1452 & 103.71 & 300.39 & 34.52 \\
\hline & $\begin{array}{l}\text { school } \\
\text { environment }\end{array}$ & 23 & 2342 & 101.82 & & 33.89 \\
\hline $\begin{array}{l}\text { Society } \\
\text { Environment }\end{array}$ & 7 & 664 & 94.854 & & 31.57 \\
\hline
\end{tabular}

\subsubsection{Data of variable student achievement $(Y)$}

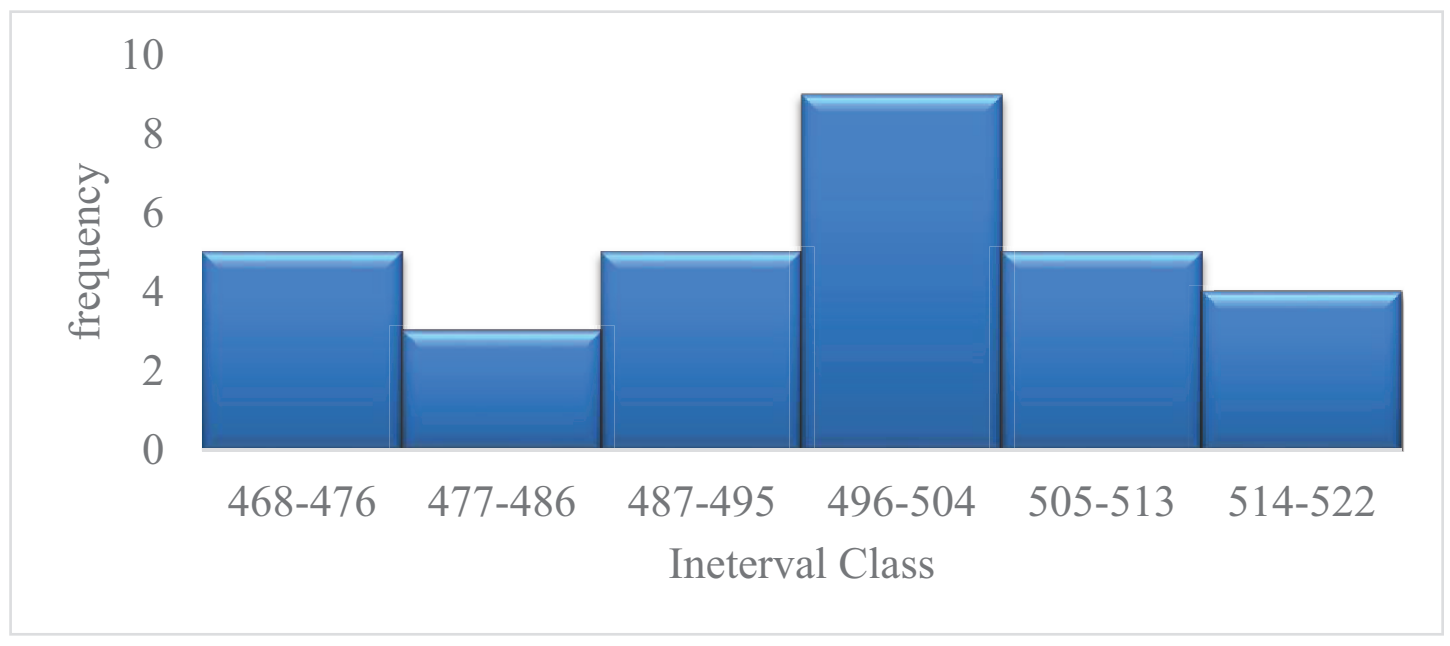

Figure 4: Histogram variable Student Achievement.

From the results of calculations such as in table 4, it can be concluded that student learning achievements include; The indicator under the KKM is $0 \%$, the indicator above the $\mathrm{KKM}$ is $100 \%$. 
TABLE 4: Average Score Calculate variable Y indicator Student Achievement.

variable
Student
achievment

Indicators
Under the
criteria (75)
Above the
criteria (75)

\begin{tabular}{|c|}
\hline Students \\
\hline 0 \\
\hline 31 \\
\hline
\end{tabular}

\begin{tabular}{|c|}
\hline $\begin{array}{c}\text { Total } \\
\text { Value }\end{array}$ \\
\hline 0 \\
\hline 2565 \\
\hline
\end{tabular}

\begin{tabular}{|c|}
\hline $\begin{array}{c}\text { Average } \\
\text { Value }\end{array}$ \\
0 \\
\hline 82.75 \\
\hline
\end{tabular}

\begin{tabular}{|c|c|}
\hline $\begin{array}{c}\text { Total } \\
\text { Average }\end{array}$ & Value \% \\
\hline 82.75 & 0 \\
\hline & 100 \\
\hline
\end{tabular}

TABLE 5: Results Of Hypotesis Test.

\begin{tabular}{|c|c|c|c|c|c|c|}
\hline & $\mathbf{R}_{\text {count }}$ & $\mathbf{R}_{\text {fable }}$ & $\mathbf{F}_{\text {count }}$ & $F_{\text {table }}$ & $\begin{array}{c}\text { Achievement } \\
\text { Contribution }\end{array}$ & Simple Linear Regression \\
\hline \multirow[b]{2}{*}{ HYPOTESIS 1} & 0,363 & 0,361 & 16,55 & 3,32 & $13,21 \%$ & \multirow[b]{2}{*}{$\hat{Y}=607,91-0,96 \mathrm{X}$} \\
\hline & \multicolumn{2}{|c|}{$\begin{array}{c}R_{\text {count }}>R_{\text {table }} \\
\text { there is a positive } \\
\text { effect }\end{array}$} & \multicolumn{2}{|c|}{$\begin{array}{c}F_{\text {count }}>F_{\text {table }} \\
\text { there is a significant } \\
\text { effect }\end{array}$} & $\begin{array}{c}86,78 \% \\
\text { determined } \\
\text { another } \\
\text { variable } \\
\end{array}$ & \\
\hline \multirow[b]{2}{*}{ HYPOTESIS 2} & 0,377 & 0,361 & 17,55 & 3,32 & $14,21 \%$ & \multirow[b]{2}{*}{$\hat{Y}=593,96-0,67 X$} \\
\hline & \multicolumn{2}{|c|}{$\begin{array}{c}R_{\text {count }}>R_{\text {table }} \\
\text { there is a positive } \\
\text { effect }\end{array}$} & \multicolumn{2}{|c|}{$\begin{array}{c}\mathrm{F}_{\text {count }}>\mathrm{F}_{\text {table }} \\
\text { there is a significant } \\
\text { effect }\end{array}$} & $\begin{array}{c}85,78 \% \\
\text { determined } \\
\text { another } \\
\text { variable }\end{array}$ & \\
\hline \multirow[b]{2}{*}{ HYPOTESIS 3} & 0,424 & 0,361 & 10,33 & 3,32 & $18,02 \%$ & \\
\hline & \multicolumn{2}{|c|}{$\begin{array}{c}R_{\text {count }}>R_{\text {table }} \\
\text { there is a positive } \\
\text { effect }\end{array}$} & \multicolumn{2}{|c|}{$\begin{array}{c}\mathrm{F}_{\text {count }}>\mathrm{F}_{\text {table }} \\
\text { there is a significant } \\
\text { effect }\end{array}$} & $\begin{array}{c}81,98 \% \\
\text { determined } \\
\text { another } \\
\text { variable }\end{array}$ & $\hat{\gamma}=615,73-0,52 x_{1}-0,41 x_{2}$ \\
\hline
\end{tabular}

\section{Discussion}

\subsection{Analysis of effect teacher competence (X1) of the student achievement(Y)}

The study hypothesis is that there is a positive and significant effect of teacher competence on learning achievement Lightweight Vehicle Engineering Program.

Based on the calculation, because $r_{\text {count }}=0,63$ with $d f=31-1=30$ for $\alpha=5 \%$ with $r_{\text {table }}$ $=0,361$. Because the $r_{\text {count }}>r_{\text {table }}$ we conclude that $H_{1}$ is accepted. From the test results $F_{\text {count }}(16,55)>F_{\text {table }}(3,32)$, then there is a significant influence between the variables $\mathrm{X}_{1}$ and variable $\mathrm{Y}$. Can be concluded that the contribution of student achievement is determined by the competency of teachers by $13.21 \%$ and the rest $86.78 \%$ is determined by other variables.

Simple linear regression analysis of the research data pairs between teacher competence and student achievement produces regression coefficients (b) of -0.96 and a constant (a) of 607.91. From the calculation, the regression equation used to predict student achievement based on the competence of teachers is $Y=607.91-0.96 X$. 


\subsection{Analysis of effect learning environment $(\mathrm{X} 2)$ of the student achievement $(\mathrm{Y})$}

The study hypothesis is that there is a positive and significant influence student learning environment on student achievement Lightweight Vehicle Engineering Program.

Based on the calculation, the known value of $r_{\text {count }}$ the $=0.377 \mathrm{df}=31-1=30$ for $\alpha=$ $5 \%$ with $r_{\text {table }}=0.361$. Because the $r_{\text {count }}>r_{\text {table }}$ we conclude that $H_{1}$ is accepted. From the test results $F_{\text {count }}(17.55)>F_{\text {table }}$ (3.32), then there is a significant influence between the variables $\mathrm{X} 2$ and variable $\mathrm{Y}$. It can be concluded that the contribution of student achievement is determined by the students' learning environment by $14.21 \%$ and the remaining $85.78 \%$ is determined by other variables.

Simple linear regression analysis from a pair of research data between the student learning environment and student achievement produces a regression coefficient (b) -0.67 and a constant (a) of 593.96. From the calculation, the regression equation used to predict student achievement based learning environment is $Y=593.96-0.67 X$.

\subsection{Analysis of effect teacher competence (X1) and learning environment $(X 2)$ of the student achievement $(Y)$}

The study hypothesis is that there is a positive effect of teacher competence and student learning environment on student achievement Lightweight Vehicle Engineering Program.

Based on the calculation, because of $r_{\text {count }}$ the $=0.424 \mathrm{df}=31-1=30$ for $\alpha=5 \%$ with $r_{\text {table }}=0.361$. Because the $r_{\text {count }}>r_{\text {table }}$, we conclude that $\mathrm{H} 1$ is accepted. From the test results $F_{\text {count }}(10.33)>F_{\text {table }}$ (3.32), then there is a significant influence between the variables $\mathrm{X} 1$ and $\mathrm{X} 2$ to variable $\mathrm{Y}$. It can be concluded that the contribution of student achievement is determined by the competence of teachers and the learning environment of students amounting to $18.02 \%$ and the remaining $81.97 \%$ is determined by other variables.

Multiple regression analysis of the research data pairs between teacher competence and student learning environment on student achievement regression coefficient (c) of -0.41 (b) of -0.52 and a constant (a) of 615.73 . From the calculation, the regression equation used to predict student achievement based on the competence of teachers and the learning environment of students is $Y=615.73-0.52 \times 1-0.41 \times 2$. 


\section{Conclusion}

Based on the objectives and results of the research, it can be concluded that:

1. Based on the statistical data management correlation coefficient calculation result of teacher competence on student achievement obtained $r_{\text {count }}$ by 0.363 and significance $5 \% r_{\text {table }}$ at 0.361 . And the test results $F_{\text {count }}(16.55)>F_{\text {table }}$ (3.32), then there is a significant influence between the variables of teacher competence and student achievement variables. It shows there is a positive and significant effect of teacher competence in student achievement program light vehicle engineering expertise. While based on the calculation of the coefficient of determination concluded that the contribution of student achievement is determined by the competency of teachers by $13.21 \%$ and the remaining $86.78 \%$ is determined by other variables. To predict student achievement based on the competence of teachers is $Y=607.91-0.96 \mathrm{X}$, the greater the competence of the teacher, the more student achievement.

2. Based on statistical data management the results of calculation of correlation coefficient learning environment on student achievement obtained $r_{\text {count }}$ of 0.377 and a $5 \%$ significance $r_{\text {table }}$ at 0.361 . And the test results $F_{\text {count }}(17.55)>F_{\text {table }}$ (3.32), the significant difference between the learning environment variables and variable student achievement. It shows there is a significant and positive impact the learning environment of students with student achievement program light vehicle engineering expertise. While based on the calculation of the coefficient of determination concluded that the contribution of student achievement is determined by the students' learning environment by $14.21 \%$ and the remaining $85.78 \%$ is determined by other variables. To predict student achievement based on students' learning environment is $Y=593.96-0.67 X$, the greater the learning environment, the more student achievement.

3. Based on the results of the management of statistical data correlation coefficient calculation competence of teachers and the learning environment on student achievement obtained $r_{\text {count }}$ of 0.42 and a $5 \%$ significance $r_{\text {table }}$ at 0.361 . And the test results $F_{\text {count }}(10.33)>F_{\text {table }}$ (3.32), then there is a significant influence between the variables of teacher competence and student learning environment to variable student achievement. It shows there is a positive and significant influence learning environment with student achievement program light vehicle engineering expertise. While based on the calculation of the coefficient of determination concluded 
that the contribution of student achievement is determined by the competence of teachers and the learning environment of students amounted to $18.02 \%$ and the remaining $81.97 \%$ is determined by other variables. To predict student achievement based on the competence of teachers and the learning environment of students is $Y=615,73-0.52 X 1-0,41 X 2$, the greater the competence of teachers $(X 1)$ and the student learning environment $(X 2)$ then the achievement student learning.

\section{Acknowledgement}

The authors would like to thank their colleague for their contribution and support to the research. They are also thankful to all the reviewers who gave their valuable inputs to the manuscript and helped in completing the paper.

\section{Conflict of Interest}

The authors have no conflict of interest to declare.

\section{References}

[1] (2003) Article 3 of the Law of the Republic of Indonesia Number 20.

[2] Evans (1999). Vocational Education. Jakarta: Rajawali Pers.

[3] Nessipbayeva, Olga. (2016). The Competencies Of The Modern Teacher. Kazakhstan: Suleyman Demirel

[4] National Research Council. 2000. How People Learn: Brain, Mind, Experience, and School: Expanded Edition. Washington, DC: The National Academies Press. https: //doi.org/10.17226/9853.

[5] Purwanto, Ngalim. (2006). Educational Psychology. Bandung: PT. Remaja Rosdakarya.

[6] Winkel, W.S. (1996). Teaching Psychology. Jakarta: Grasindo.

[7] Sugiyono. (2007) Educational Research Methods. Bandung: Alfabeta.

[8] Suharsimi Arikunto. (2009). Research procedure. Jakarta: Rineka cipta 